American Journal of Applied Sciences 6 (6): 1076-1085, 2009

ISSN 1546-9239

(C) 2009 Science Publications

\title{
Profiling of Phenolic Compounds of Somatic and Reproductive Tissues of Agave Durangensis Gentry (Agavaceae)
}

\author{
Norma Almaraz-Abarca, Elí Amanda Delgado-Alvarado, Vicente Hernández-Vargas, \\ Margarita Ortega-Chávez, Gildardo Orea-Lara, Armando Cifuentes-Díaz de León, \\ José Antonio Ávila-Reyes and Raúl Muñiz-Martínez \\ Interdisciplinary Research Centre for Integral Regional Development-Durango, \\ National Polytechnique Institute (CIIDIR-IPN-Dgo.), Sigma s/n, Durango, Dgo., Mexico, 34220
}

\begin{abstract}
Problem statement: In Durango, Mexico, mescal is elaborated from wild plants of Agave durangensis. This species shows a high morphological variability within and among populations, what makes its taxonomic delimitation a hard task. Approach: In this study the pollen and foliar phenolic compositions of Agave durangensis were analyzed by HPLC/DAD with the aim of determining the significance of phenol profiles to delimit this taxon. Results: The foliar phenol compositions were evaluated within and among two populations and between juvenile and adult plants. Agave asperrima Jacobi, Dasylirion sp. and juvenile samples of A. shrevei Gentry subsp. shrevei, A. shrevei Gentry subsp. matapensis Gentry and A. wocomahi Gentry, were also analyzed to stand comparisons with. The results from this study indicated that pollen and foliar tissues of Agave durangneisis were rich in kaempferol glycoside derivatives (13 and 23 different compounds can be present, respectively). Principal coordinates analysis (PCO), based on foliar profiles of adults, indicated the presence of several chemotypes within the Type locality of Agave durangensis and revealed chemical differences between the both analyzed populations. Conclusion/Recommendations: Chemical and morphological differences and biogeographical evidence suggest the recognition of two different taxonomic entities in this morphological variable group.
\end{abstract}

Key words: Pollen flavonoids, foliar flavonoid profiles, Agave phenolic variability

\section{INTRODUCTION}

Agave is the biggest genus of the family Agavaceae, with around 166 species, from which 125 grow in Mexico ${ }^{[1,2]}$. Relevant ethnobotanic relationships have been established between the elements of this genus and the ancient and present cultures of Mexico ${ }^{[3,4]}$. Several authors have described the use of Agave as source of fibers, food and beverages ${ }^{[5]}$. In addition, Agave is used as natural fences to avoid the soil erosion and as cattle food ${ }^{[6]}$.

At the present, the relevance of Agave has increased meanly because of the increased demand of alcoholic beverages like tequila and mescal ${ }^{[7]}$ and the research on potential sources of prebiotics ${ }^{[8]}$. In all the cases, the authentification of the species of Agave to be used is an important requirement in the quality control of the manufacturing processes. In Mexico, with exception of Agave tequilana Weber var. azul, species like Agave durangensis, which support local industries of alcoholic beverages and which with just begin an industrialization process, techniques are needed to guarantee the botanical origin of plants, according to the respective origin denomination statement.

Agave durangensis Gentry is one of the 24 species of genus Agave occurring in Durango, Mexico ${ }^{[9]}$. This species belongs to group Ditepalae of subfamily Agavoideae, proposed by Gentry ${ }^{[3]}$ and can be found from Southern Durango to Northern Zacatecas ${ }^{[3,10]}$.

In two localities of Durango ("Sierra of Registro", the type locality and "Mezquital"), populations of Agave, traditionally called "agave mezcalero" or "agave cenizo", presumably A. durangensis, maintains a thriving mescal industry. Actually, studies have not been done to confirm that in all the cases the raw material to elaborate mescal is composed of that species $^{[10]}$. In Durango, the manufacturing of mescal is mainly based on the gathering of agaves from their natural populations ${ }^{[7]}$. Recently, producers have been interested in the establishment of plantations of

Corresponding Author: Norma Almaraz-Abarca, Interdisciplinary Research Centre for Integral Regional Development-Durango, National Polytechnique Institute (CIIDIR-IPN-Dgo.), Sigma s/n, Durango, Dgo., Mexico, 34220 Tel/Fax: (52 618) 8142091 
A. durangensis and then, typification methods are needed to guarantee the botanical origin of plants, since genus Agave is taxonomically difficult, owing to the high degree of phenotypic plasticity, the occurrence of several ploidy levels and the high capacity of hybridization $^{[3,4]}$. Previous reports ${ }^{[3]}$ and our own field observations in the Type locality ("Sierra of Registro", Durango, Mexico) indicate that A. durangensis is highly variable in size, color of leaf and size and form of teeth, in such a way that it has been suggested as a complex of species more than a single species by some authors ${ }^{[7]}$. Chemical characterization is an important technique, which with plant typification and identification can be made in a relative easy and fast manner, as it has been reported for many groups of plants $^{[11,12]}$.

In the literature there are many reports describing the significance of phenol profiles to discriminate among different related taxa ${ }^{[13-15]}$. The species-specific tendency of pollen ${ }^{[12,16,17]}$ and somatic tissues phenol profiles $^{[18,19]}$ has been reported for many species of plants. In spite of the economic and ecologic importance and the taxonomic controversies prevailing in the delimitation of the different species of the genus Agave and in the other hand, in spite of the taxonomic relevance of phenol composition, the efforts focused in determining the taxonomic significance of the phenol profiles in this genus has been limited.

Agave is rich in saponins and it has been better analyzed by its saponin composition ${ }^{[20-23]}$ than any other secondary metabolite. One of the few species of Agave analyzed by its phenol composition is Agave americana, in which complex flavonoids has been found in somatic tissues, like 5,7-dihydroxy-6,5'-dimethoxy-3',4'methylenedioxyflavanona ${ }^{[24]}$ and kaempferol-3glycoside derivatives were detected in flowers ${ }^{[25]}$. In this study the phenol characterization of somatic and reproductive tissues of Agave durangensis was performed, using high pressure liquid chromatography/diode array detector (HPLC/DAD) profiles in order to establish the specific taxonomic significance of these markers and to detect intra and interpopulation variability. Moreover, to our knowledge, the phenolic composition of Agave durangensis and A. asperrima is reported for the first time.

\section{MATERIALS AND METHODS}

Plant material: Foliar tissue from 23 adult plants (no less than 22 leaves) of each two populations of Agave durangensis, were analyzes for their phenol composition by HPLC/DAD. With comparative aims, an equal number of individuals of Agave asperrima was collected and analyzed in the same manner. Mature flowers of four individuals from two different populations of $A$. durangensis were also collected for phenol composition analysis. Nineteen juvenile foliar samples of $A$. durangensis (plants of no more than eight leaves) were as well collected and analyzed for phenol composition. Reference samples were deposited at Herbarium CIIDIR. Juvenile foliar samples of Agave shrevei subsp. shrevei (28785), A. shrevei subsp. matapensis (AG-8922), Agave wocomahi (28891) and Agave durangensis (AG-5973), all donated by Dr. Abisai García-Mendoza, from the National Colection of Agavaceas, Botanic Garden, Biology Institut, UNAM and foliar samples of Dasylirion sp. (Nolinaceae) from four individuals growing at CIIDIR-IPN-Dgo., were analyzed for comparisons. The ecogeography profile for each sampling sites is shown in Table 1. Additionally, information about the morphological features was recorder for each sample.

Phenol extraction: Each sample was individually treated. Five grams of foliar dried grinded tissue were firstly extracted by maceration for $24 \mathrm{~h}$, in $100 \mathrm{~mL} 60 \%$ methanol (v/v), in darkness and at room temperature.

Table 1: Collection sites for Agave durangensis and Agave asperrima

\begin{tabular}{|c|c|c|c|c|c|c|c|c|c|}
\hline Sample & $\begin{array}{l}\text { No. } \\
\text { Ref. }\end{array}$ & Species & Location & $\begin{array}{l}\text { Latitude } \\
\mathrm{N}\end{array}$ & LongitudeW & $\begin{array}{l}\text { Altitude } \\
(\mathrm{m})\end{array}$ & Soil & $\begin{array}{l}\text { Associated } \\
\text { vegetation }\end{array}$ & Date \\
\hline 1 and 2 & $\begin{array}{l}531 \text { and } \\
533\end{array}$ & A. durangensis & $\begin{array}{l}\text { Temoaya, } \\
\text { Mezquital, Durango }\end{array}$ & $23^{\circ} 29^{\prime} 04^{\prime \prime}$ & $104^{\circ} 26^{\prime} 31^{\prime \prime}$ & 1780 & Gravel & $\begin{array}{l}\text { Dasylirium sp., Lippia sp., } \\
\text { Selaginella sp., Acacia sp. }\end{array}$ & Jun 08 \\
\hline 3 and 4 & $\begin{array}{l}601 \text { and } \\
603\end{array}$ & A. durangensis & $\begin{array}{l}\text { Mezquital, } \\
\text { Durango }\end{array}$ & $23^{\circ} 37^{\prime} 47^{\prime \prime}$ & $104^{\circ} 22^{\prime} 08^{\prime \prime}$ & 1855 & Gravel & $\begin{array}{l}\text { Dasylirium sp., } \\
\text { Bursera sp., Lippia sp. }\end{array}$ & Jun 08 \\
\hline $5-27$ & $202-233$ & A. durangensis & $\begin{array}{l}\text { Sierra El } \\
\text { Registro, Durango }\end{array}$ & $23^{\circ} 59^{\prime} 38^{\prime}$, & $104^{\circ} 22.5^{\prime} 13^{\prime \prime}$ & 1928 & Sandy & $\begin{array}{l}\text { Prosopis sp. Acacia sp., } \\
\text { Dasylirium } \mathrm{sp} .\end{array}$ & Jun 08 \\
\hline $28-50$ & $500-533$ & A. durangensis & $\begin{array}{l}\text { Temoaya, } \\
\text { Mezquital, Durango }\end{array}$ & $23^{\circ} 29^{\prime} 04^{\prime \prime}$ & $104^{\circ} 26^{\prime} 31^{\prime \prime}$ & 1780 & Gravel & $\begin{array}{l}\text { Dasylirium sp., Lippia sp., } \\
\text { Selaginela sp., Acacia sp. }\end{array}$ & Jun 08 \\
\hline $51-73$ & $300-333$ & A. asperrima & $\begin{array}{l}\text { Cuencamé, } \\
\text { Durango }\end{array}$ & $25^{\circ} 01^{\prime} 0.5^{\prime \prime}$ & $103^{\circ} 45^{\prime} 51^{\prime \prime}$ & 1442 & Gravel & $\begin{array}{l}\text { Opuntia sp., } \\
\text { Fouqueiria sp., Euphorbia } \\
\text { antisyphilitica, Larrea } \\
\text { tridentate }\end{array}$ & Jun 08 \\
\hline
\end{tabular}


The extracts were centrifuged (5000 rpm), for $10 \mathrm{~min}$, at room temperature. The supernatants were separated. The pellets were reextracted in $100 \mathrm{~mL} 60 \%$ methanol (v/v) by maceration for $3 \mathrm{~h}$. The extracts were centrifuged at the same conditions. The similar supernatants were brought together and formed the total extracts. Each total extract was concentrated under vacuum to dryness and then resolved in $5 \mathrm{~mL}$ methanol; aliquots were taken to be used in the HPLC/DAD analysis.

Samples of pollen collected directly from anthers were individually extracted according to Campos ${ }^{[11]}$, with ethanol-water $(50 \% \mathrm{v} / \mathrm{v})$ and sonicated for $60 \mathrm{~min}$. The resultant mixtures were centrifuged for $10 \mathrm{~min}$ and the supernatants used for HPLC/DAD analysis.

HPLC/DAD analysis: To determine the HPLC/DAD phenolic profiles, extracts $(20 \mu \mathrm{L})$ were analyzed as previously described ${ }^{[16]}$, on a Perkin Elmer HPLC system and Perkin Elmer Brownlee Analytical C18 column $(4.6 \times 250 \mathrm{~mm}, 5 \mu \mathrm{m})$, by an acidified acetonitrile-water gradient. Standard chromatograms were plotted at 260 and $340 \mathrm{~nm}$. Spectral data for all peaks were accumulated in the range $220-400 \mathrm{~nm}$ using diode-array detection (Perkin Elmer Series 200). The structural identifications were made by direct comparison of retention time and UV spectra of standards and according to ${ }^{[26,27]}$.

Data analysis: The phenol profile of each sample was made up of all compounds resolved in their respective HPLC/DAD chromatograms. Each compound was treated as a single chemical character. A binary matrix of presence-absence formed by all individual samples vs. all resolved compounds, for each adult and juvenile samples, were analyzed by principal coordinates analysis (PCO) from NTSyS $1.8^{[28]}$.

\section{RESULTS}

Pollen phenol composition: The relation of phenolic compounds found in pollen of Agave durangensis is shown in Table 2. Retetion times and the chemical identification are included. Individual variability can be observed.

Foliar phenol composition: The resolved flavonoid compounds for all the 23 individuals of Agave durangensis from Sierra of Registro are presented in Table 3. The individual foliar phenolic profiles of each sample from the population of "Temoaya" are indicated in Table 4; while those corresponding to A. asperrima are shown in Table 5. In all these cases, the retention times and the chemical identification are included. As in pollen, variability among the individual profiles can be observed.

The foliar phenol profiles of each of the four analyzed individuals of Dasylirion sp. are showed in Table 6. Contrary to that observed for samples of Agave, individual variability was not observed.

Principal coordinates analysis: The discrimination of taxa based on the foliar phenol composition of adults, according to the PCO analysis, is showed in Fig. 1. The clear segregation of Dasylirion sp., A. asperrima and A. durangensis from "Temoaya" can be observed. However, three subgroups in the mayor group of A. durangensis from Sierra of Registro can be distinguished. The PCO analysis, based on the foliar phenol composition of juvenils, is showed in Fig. 2. The segregation of samples of $A$. shrevei subsp. shrevei, A. shrevei subsp. matapensis and A. wocomahi and the inclution of the sample of $A$. durangensis from the Botanic Garden, UNAM, in the mayor group formed by the most of the juvenile samples of A. durangensis from Sierra of Registro can be observed.

Table 2: Chromatographic data for pollen phenol compounds of Agave durangensis

\begin{tabular}{|c|c|c|c|c|c|c|}
\hline Compound & Retention time $(\mathrm{min})^{*}$ & Chemical identification & 531 & 533 & 601 & 603 \\
\hline P1 & $28.349 \pm 0.020$ & Kaempferol glycoside & + & + & + & + \\
\hline P2 & $29.491 \pm 0.050$ & Kaempferol glycoside & + & + & - & - \\
\hline P3 & $31.618 \pm 0.053$ & Kaempferol glycoside & - & - & + & + \\
\hline $\mathrm{P} 4$ & $29.938 \pm 0.000$ & Kaempferol glycoside & + & - & - & - \\
\hline P5 & $31.917 \pm 0.115$ & Kaempferol glycoside & - & - & + & + \\
\hline P6 & $30.716 \pm 0.000$ & Kaempferol glycoside & + & - & - & - \\
\hline $\mathrm{P} 7$ & $31.836 \pm 0.000$ & Kaempferol glycoside & - & + & - & - \\
\hline P8 & $32.149 \pm 0.049$ & Kaempferol-3-O-[glucosyl(1-2)glucoside] & - & - & + & + \\
\hline P9 & $32.537 \pm 0.000$ & Myricetin-3-O-rhamnoside & - & - & + & + \\
\hline $\mathrm{P} 10$ & $31.985 \pm 0.060$ & 7-O-methylkaempferol-3-O-[rhamnosyl(1-2)glucoside] & + & + & - & - \\
\hline P11 & $33.118 \pm 0.219$ & Kaempferol glycoside & - & - & + & + \\
\hline $\mathrm{P} 12$ & $35.198 \pm 0.033$ & Kaempferol-3-O-glucoside & + & + & - & - \\
\hline \multirow[t]{2}{*}{$\mathrm{P} 13$} & $37.5305 \pm 0.303$ & Kaempferol glycoside & + & + & - & - \\
\hline & & Total & 7 & 6 & 6 & 6 \\
\hline
\end{tabular}

+: Present; -: Absent; *: Mean and standard deviation 
Am. J. Applied Sci., 6 (6): 1076-1085, 2009

Table 3: Individual distribution of foliar flavonoid compounds of Agave durangensis from "Sierra of Registro"

\begin{tabular}{|c|c|c|c|c|c|c|c|c|c|c|c|c|c|c|c|c|c|c|c|c|c|c|c|c|c|}
\hline Comp. & $\begin{array}{l}\text { Retention } \\
\text { time (min) }\end{array}$ & $\begin{array}{l}\text { Chem. } \\
\text { Ident. }\end{array}$ & 200 & 201 & 202 & 203 & 204 & 206 & 209 & 210 & 211 & 213 & 214 & 216 & 218 & 219 & 221 & 224 & 225 & 228 & 229 & 230 & 231 & 232 & 233 \\
\hline $\mathrm{F} 1$ & $18.227 \pm 0.093$ & KG & 0 & 0 & 0 & 0 & 0 & 0 & 0 & 0 & 0 & 1 & 0 & 0 & 1 & 0 & 0 & 0 & 0 & 0 & 0 & 0 & 0 & 0 & 0 \\
\hline $\mathrm{F} 2$ & $18.865 \pm 0.00$ & KG & 0 & 0 & 0 & 0 & 0 & 0 & 0 & 0 & 0 & 1 & 0 & 0 & 0 & 0 & 0 & 0 & 0 & 0 & 0 & 0 & 0 & 0 & 0 \\
\hline F3 & $19.598 \pm 0.035$ & KG & 0 & 0 & 0 & 0 & 0 & 0 & 0 & 0 & 0 & 1 & 0 & 0 & 0 & 0 & 0 & 0 & 0 & 0 & 0 & 0 & 1 & 0 & 0 \\
\hline F4 & $22.489 \pm 0.042$ & KG & 0 & 0 & 0 & 0 & 0 & 0 & 0 & 0 & 0 & 1 & 1 & 0 & 1 & 1 & 0 & 1 & 0 & 1 & 0 & 0 & 0 & 0 & 0 \\
\hline F5 & $23.326 \pm 0.089$ & KG & 0 & 0 & 0 & 1 & 1 & 0 & 1 & 0 & 0 & 0 & 0 & 0 & 1 & 0 & 0 & 0 & 0 & 0 & 0 & 0 & 0 & 0 & 0 \\
\hline F6 & $24.438 \pm 0.00$ & KG & 0 & 0 & 0 & 0 & 0 & 0 & 0 & 0 & 0 & 1 & 0 & 0 & 0 & 0 & 0 & 0 & 0 & 0 & 0 & 0 & 0 & 0 & 0 \\
\hline F7 & $25.142 \pm 0.00$ & QG & 0 & 0 & 0 & 0 & 0 & 0 & 0 & 0 & 0 & 0 & 0 & 0 & 0 & 0 & 0 & 0 & 0 & 1 & 0 & 0 & 0 & 0 & 0 \\
\hline F8 & $27.067 \pm 0.00$ & $\mathrm{QG}$ & 0 & 0 & 0 & 1 & 0 & 0 & 0 & 0 & 0 & 0 & 0 & 0 & 0 & 0 & 0 & 0 & 0 & 0 & 0 & 0 & 0 & 0 & 0 \\
\hline F9 & $27.710 \pm 0.060$ & KG & 0 & 0 & 0 & 0 & 0 & 0 & 0 & 0 & 0 & 1 & 0 & 0 & 0 & 0 & 0 & 0 & 1 & 1 & 0 & 0 & 0 & 0 & 0 \\
\hline F10 & $28.313 \pm 0.014$ & KG & 0 & 0 & 1 & 0 & 0 & 0 & 0 & 0 & 0 & 0 & 1 & 0 & 0 & 0 & 0 & 0 & 0 & 0 & 1 & 1 & 0 & 0 & 1 \\
\hline F11 & $27.623 \pm 0.051$ & $\mathrm{~K} 3,7 \mathrm{OG}$ & 1 & 1 & 1 & 0 & 1 & 1 & 1 & 1 & 1 & 1 & 1 & 1 & 1 & 1 & 1 & 1 & 1 & 0 & 1 & 1 & 1 & 0 & 0 \\
\hline F12 & $29.955 \pm 0.104$ & KG & 0 & 0 & 0 & 0 & 0 & 0 & 0 & 0 & 0 & 0 & 0 & 0 & 0 & 0 & 0 & 0 & 0 & 0 & 0 & 0 & 0 & 0 & 0 \\
\hline F13 & $29.969 \pm 0.090$ & $\mathrm{KAcG}$ & 0 & 0 & 0 & 1 & 0 & 0 & 0 & 1 & 0 & 0 & 0 & 0 & 0 & 0 & 0 & 0 & 0 & 0 & 0 & 0 & 1 & 0 & 0 \\
\hline F14 & $31.610 \pm 0.056$ & KG & 0 & 0 & 0 & 0 & 0 & 0 & 0 & 0 & 0 & 0 & 0 & 0 & 0 & 0 & 0 & 0 & 0 & 0 & 0 & 0 & 0 & 0 & 0 \\
\hline F15 & $31.434 \pm 0.131$ & KG & 1 & 1 & 1 & 1 & 1 & 1 & 1 & 1 & 1 & 0 & 1 & 1 & 0 & 1 & 1 & 1 & 1 & 1 & 1 & 1 & 1 & 0 & 1 \\
\hline F16 & $32.506 \pm 0.126$ & KG & 0 & 0 & 0 & 0 & 1 & 0 & 0 & 0 & 1 & 0 & 1 & 1 & 1 & 0 & 1 & 1 & 1 & 0 & 1 & 1 & 0 & 1 & 1 \\
\hline F17 & $33.238 \pm 0.095$ & KG & 0 & 0 & 0 & 0 & 0 & 0 & 0 & 0 & 0 & 0 & 0 & 0 & 0 & 0 & 0 & 0 & 0 & 0 & 0 & 0 & 0 & 0 & 0 \\
\hline F18 & $33.609 \pm 0.051$ & KG & 0 & 0 & 0 & 0 & 0 & 0 & 0 & 0 & 0 & 0 & 0 & 0 & 0 & 0 & 0 & 0 & 0 & 0 & 0 & 1 & 1 & 0 & 1 \\
\hline F19 & $34.937 \pm 0.086$ & KRhG & 0 & 0 & 0 & 0 & 0 & 0 & 0 & 0 & 0 & 0 & 0 & 0 & 0 & 0 & 0 & 1 & 0 & 0 & 0 & 1 & 0 & 0 & 0 \\
\hline F20 & $34.720 \pm 0.00$ & QA & 0 & 0 & 0 & 0 & 0 & 0 & 0 & 0 & 0 & 0 & 0 & 0 & 0 & 0 & 0 & 0 & 1 & 0 & 0 & 0 & 0 & 0 & 0 \\
\hline F21 & $35.603 \pm 0.154$ & $\mathrm{~K}$ & 0 & 0 & 0 & 0 & 0 & 0 & 0 & 0 & 0 & 0 & 0 & 0 & 0 & 0 & 0 & 0 & 0 & 0 & 0 & 0 & 0 & 0 & 0 \\
\hline $\mathrm{F} 22$ & $35.445 \pm 0.046$ & KG & 0 & 0 & 0 & 0 & 0 & 0 & 0 & 1 & 0 & 0 & 0 & 0 & 0 & 0 & 0 & 1 & 0 & 0 & 0 & 0 & 0 & 0 & 0 \\
\hline $\mathrm{F} 23$ & $37.148 \pm 0.169$ & KG & 0 & 0 & 0 & 0 & 0 & 0 & 0 & 0 & 0 & 0 & 0 & 0 & 0 & 0 & 0 & 0 & 0 & 0 & 0 & 0 & 0 & 0 & 0 \\
\hline F24 & $38.191 \pm 0.030$ & $\mathrm{KRh}$ & 1 & 1 & 1 & 1 & 1 & 1 & 1 & 0 & 1 & 0 & 1 & 0 & 0 & 1 & 1 & 1 & 1 & 1 & 1 & 1 & 0 & 1 & 1 \\
\hline F25 & $37.198 \pm 0.096$ & KG & 0 & 0 & 0 & 0 & 0 & 0 & 0 & 0 & 0 & 0 & 1 & 1 & 0 & 1 & 0 & 0 & 0 & 0 & 0 & 0 & 0 & 0 & 0 \\
\hline F26 & $38.577 \pm 0.236$ & KG & 0 & 0 & 0 & 1 & 0 & 0 & 0 & 0 & 0 & 0 & 0 & 0 & 0 & 0 & 0 & 0 & 0 & 1 & 0 & 0 & 0 & 1 & 0 \\
\hline F27 & $38.874 \pm 0.00$ & KG & 0 & 0 & 0 & 0 & 0 & 0 & 0 & 0 & 0 & 0 & 0 & 0 & 0 & 0 & 0 & 0 & 0 & 0 & 0 & 0 & 0 & 0 & 0 \\
\hline F28 & $40.004 \pm 0.120$ & KG & 0 & 0 & 0 & 0 & 0 & 0 & 0 & 0 & 0 & 0 & 0 & 0 & 0 & 0 & 0 & 0 & 0 & 0 & 0 & 0 & 0 & 0 & 0 \\
\hline F29 & $40.074 \pm 0.00$ & KG & 0 & 0 & 0 & 0 & 0 & 0 & 0 & 0 & 0 & 0 & 0 & 0 & 0 & 0 & 0 & 0 & 0 & 0 & 0 & 1 & 0 & 0 & 0 \\
\hline F30 & $40.924 \pm 0.00$ & KG & 0 & 0 & 0 & 0 & 0 & 0 & 0 & 0 & 0 & 0 & 0 & 0 & 0 & 0 & 0 & 0 & 0 & 0 & 0 & 1 & 0 & 0 & 0 \\
\hline F31 & $48.528 \pm 0.057$ & KG & 0 & 0 & 0 & 0 & 0 & 0 & 0 & 0 & 0 & 0 & 0 & 0 & 0 & 0 & 0 & 0 & 0 & 0 & 0 & 0 & 0 & 0 & 0 \\
\hline F32 & $50.385 \pm 0.161$ & KG & 0 & 0 & 0 & 0 & 0 & 0 & 0 & 0 & 0 & 0 & 0 & 0 & 0 & 0 & 0 & 0 & 0 & 0 & 0 & 0 & 0 & 0 & 0 \\
\hline
\end{tabular}

*: Mean and standard deviation; KG: Kaempferol Glycoside; QG: Quercetin Glycoside; K3,7OG: Kaempferol-3,7-O-diglucoside; KAcG: Kaempferol-3-O-[6-acetylglucoside]-7-O-glucoside; KRhG: Kaempferol-3-O-[rhamnosyl(1-6) glucoside]; QA: Quercetin-3-O-arabinoside; KRh: Kaempferol-3-O-rhamnoside; 1: Present; 0: Absent

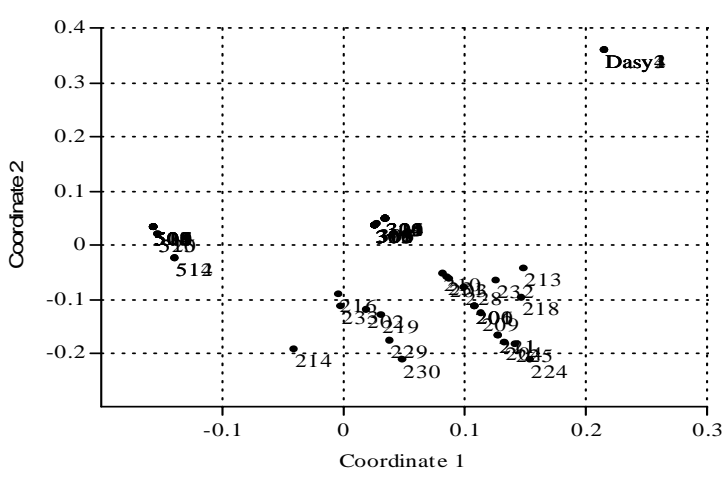

Fig. 1: Results of Principal Coordinates Analysis comparing foliar flavonoid profiles for samples of Agave durangensis from Sierra of Registro (200-233), A. durangensis from "Temoaya" (500-522), A. asperrima (300-326) and Dasylirion sp. (Dasy1-Dasy4)

\section{DISCUSSION}

Taxonomic implications of pollen phenol composition: A total of 13 different compounds were detected by HPLC/DAD (Table 2). Flavonoids were the only class of phenolics found in the pollen of Agave durangensis. The analysis revealed 12 kaempferol glycosides and one myricetin glycoside. Derivatives of both quercetin and kaempferol are the most abundant phenols in pollen ${ }^{[11,12,17,29]}$. They along with myricetin are involved in such as important functions as the pollen tube germination and growth in several species of plants ${ }^{[30,31]}$; however, in spite of quercetin glycoside derivatives are almost ubiquitous, it was significantly absent from Agave durangensis pollen. The role of the abundant kaempferol glycosides in pollen of Agave durangensis is left for determining.

The pollen phenol profile of the two individuals of Agave durangensis coming from the population of "Mezquital" were identical between them (six flavonols and the presence of one myricetin glycoside) but some 
different of those of the two individuals from "Temoaya", which were very similar between them but a little variability was detected (Table 2). These two localities are separated one from each other by $15 \mathrm{Km}$ and similar morphological traits between both populations were observed.

Variability in pollen phenol profiles has been showed for other plants, including plants sharing the habitat of $A$. durangensis in the semiarid zones of Durango, like some species of Cactaceae ${ }^{[12]}$.

The importance of pollen phenol profiles as specific taxonomic markers has been reported ${ }^{[16,17]}$. These results suggest that, although only two individuals from each population were analyzed (inflorescences of Agave durangensis are difficult to find due to it is a monocarpic species and due to when plants are ready to flower, the inflorescences stems are cut to prepare the plants for mescal manufacturing), this kind of profiles could be even used to discriminate among populations. This would be relevant because of the taxonomic controversy in the specific delimitation of A. durangensis, which is, in turn, a consequence of the high morphological variability found in this taxon ${ }^{[3,10]}$ and of the little effort dedicated to study this group. However, to propose these profiles as a specific and infraspecific marker, it is necessary to carry out more population studies, with a higher number of individuals, throughout all the geographical distribution.

Taxonomic implications of foliar phenol composition: The flavonoids of the Agave family, the Agavaceae, have not been well investigated; just a few species have been analyzed ${ }^{[32]}$, so that, this survey, basically of two species of Agave (A. durangensis and $A$. asperrima), is useful in indicating the variation that may be encountered in these plants.

A total of 32 compounds were resolved in the foliar samples of adult plants by HPLC/DAD (Table 3). The analysis revealed 23 flavonol glycosides present in the foliar profiles of Agave durangensis. Twenty of those were kaempferol glycoside derivatives. Three different quercetin glycoside derivatives were found in samples 203, 225 and 228. More phenol compounds could be present but at a very low concentration in such a way that their identification was not possible.

A high variability was found in the individual phenol profiles of the population from Sierra of Registro, which is the Type locality of Agave durangensis. Our own field observations revealed also a high morphological variability concerning the leaves form and length, adult plant height, number of teeth in $10 \mathrm{~cm}$ and terminal spine length, this variability agree to that found in the phenol composition. The profiles varied from three compounds in four individuals $(200,201,206$ and 232) to nine in the individual 230 (Table 3).
The PCO analysis based on the foliar phenol composition of the individuals from Sierra of Registro revel the presence of three major groups; these could represent three chemotypes (Fig. 1). The morphological and chemical variations could reflect a present evolution process in this taxon, which has been put under an intense environmental pressure due to the overexploitation and deforestation of the area several decades ago.

As in the case of pollen, the dominance of kaempferol derivatives was clear in the foliar phenol composition of A. durangensis (and also of Agave asperrima, Table 5). It has been suggested that certain compounds may be induced by herbivore predators or microbial attackers ${ }^{[33]}$, this could explain the presence of quercetin derivatives in few individuals (three) of Agave durangensis from the population Sierra of Registro (Table 3).

The homogeneity in the foliar phenol profiles of individuals of Agave durangensis from the population of "Temoaya" represents a strong contrast with that found for the population Sierra of Registro. Assumed as Agave durangensis, the individuals from "Temoaya" showed a profile of only three to four kaempferol glycosides (Table 4). The plants growing in "Temoaya" are in average higher $(101.3 \pm 38.718 \mathrm{~cm})$ than the plants from Sierra of Registro $(78.25 \pm 23.686 \mathrm{~cm})$ and have longer leaves $(73.7 \pm 26.765 \mathrm{~cm}$ and $54.795 \pm 16.130$ $\mathrm{cm}$, respectively), with similar middle-leaf wide $(19.2 \pm 4.134 \mathrm{~cm}$ and $18.3 \pm 4.401 \mathrm{~cm}$, respectively) and similar spine length $(4.5 \pm 1.08$ and $4.2 \pm 1.10 \mathrm{~cm}$, respectively). Both populations (Sierra of Registro and "Temoaya") are separated one from each other by around $50 \mathrm{Km}$, each with different environmental conditions (Table 1). This could explain the two classes of profiles found in one and another population, since it has been stated that the biosynthesis and accumulation of secondary metabolites depends on highly regulated processes, requiring, among others, environment-specific controls $^{[34]}$. However, it has been reported that enzymes catalyzing modification reactions of simple flavonoids generally exhibit high substrate specificity, implying that many reactions proceed in a defined sequential order, which seems to be specific for each plant species ${ }^{[35]}$; then, according to this and to the PCO analysis, the foliar phenol compositions of both populations are different in such a way that each could represent an independent taxon (Fig. 1).

González-Elizondo et al. ${ }^{[10]}$ report Agave angustifolia, A. wocomahi, A. shrevei ssp. magna and A. maximiliana occurring also in Southern Durango. The samples of "Temoaya" could belong to some of those species; however their morphological attributes do not correspond to those given by ${ }^{[0]}$ for each of mentioned species. 
Am. J. Applied Sci., 6 (6): 1076-1085, 2009

Table 4: Individual distribution of foliar flavonoid compounds of Agave durangensis from "Temoaya"

\begin{tabular}{|c|c|c|c|c|c|c|c|c|c|c|c|c|c|c|c|c|c|c|c|c|c|c|c|c|c|}
\hline Comp. & $\begin{array}{l}\text { Retention } \\
\text { time (min) }\end{array}$ & $\begin{array}{l}\text { Chem. } \\
\text { Ident. }\end{array}$ & 500 & 501 & 502 & 503 & 504 & 505 & 506 & 507 & 508 & 509 & 510 & 511 & 512 & 513 & 514 & 515 & 516 & 517 & 518 & 519 & 520 & 521 & 522 \\
\hline F1 & $18.227 \pm 0.093$ & KG & 0 & 0 & 0 & 0 & 0 & 0 & 0 & 0 & 0 & 0 & 0 & 0 & 0 & 0 & 0 & 0 & 0 & 0 & 0 & 0 & 0 & 0 & 0 \\
\hline $\mathrm{F} 2$ & $18.865 \pm 0.00$ & KG & 0 & 0 & 0 & 0 & 0 & 0 & 0 & 0 & 0 & 0 & 0 & 0 & 0 & 0 & 0 & 0 & 0 & 0 & 0 & 0 & 0 & 0 & 0 \\
\hline F3 & $19.598 \pm 0.035$ & KG & 0 & 0 & 0 & 0 & 0 & 0 & 0 & 0 & 0 & 0 & 0 & 0 & 0 & 0 & 0 & 0 & 0 & 0 & 0 & 0 & 0 & 0 & 0 \\
\hline F4 & $22.489 \pm 0.042$ & KG & 0 & 0 & 0 & 0 & 0 & 0 & 0 & 0 & 0 & 0 & 0 & 0 & 0 & 0 & 0 & 0 & 0 & 0 & 0 & 0 & 0 & 0 & 0 \\
\hline F5 & $23.326 \pm 0.089$ & KG & 0 & 0 & 0 & 0 & 0 & 0 & 0 & 0 & 0 & 0 & 0 & 0 & 0 & 0 & 0 & 1 & 0 & 0 & 0 & 1 & 0 & 0 & 0 \\
\hline F6 & $24.438 \pm 0.00$ & KG & 0 & 0 & 0 & 0 & 0 & 0 & 0 & 0 & 0 & 0 & 0 & 0 & 0 & 0 & 0 & 0 & 0 & 0 & 0 & 0 & 0 & 0 & 0 \\
\hline F7 & $25.142 \pm 0.00$ & QG & 0 & 0 & 0 & 0 & 0 & 0 & 0 & 0 & 0 & 0 & 0 & 0 & 0 & 0 & 0 & 0 & 0 & 0 & 0 & 0 & 0 & 0 & 0 \\
\hline F8 & $27.067 \pm 0.00$ & QG & 0 & 0 & 0 & 0 & 0 & 0 & 0 & 0 & 0 & 0 & 0 & 0 & 0 & 0 & 0 & 0 & 0 & 0 & 0 & 0 & 0 & 0 & 0 \\
\hline F9 & $27.710 \pm 0.060$ & KG & 0 & 0 & 0 & 0 & 0 & 0 & 0 & 0 & 0 & 0 & 0 & 0 & 0 & 0 & 0 & 0 & 0 & 0 & 0 & 0 & 0 & 0 & 0 \\
\hline F10 & $28.313 \pm 0.014$ & KG & 1 & 1 & 1 & 1 & 1 & 1 & 1 & 1 & 1 & 1 & 1 & 1 & 1 & 1 & 1 & 1 & 1 & 1 & 1 & 1 & 1 & 1 & 1 \\
\hline F11 & $27.623 \pm 0.051$ & $\mathrm{~K} 3,7 \mathrm{OG}$ & 0 & 0 & 0 & 0 & 0 & 0 & 0 & 0 & 0 & 0 & 0 & 0 & 0 & 0 & 0 & 0 & 0 & 0 & 0 & 0 & 0 & 0 & 0 \\
\hline F12 & $29.955 \pm 0.104$ & KG & 0 & 0 & 0 & 0 & 0 & 0 & 0 & 0 & 0 & 0 & 0 & 0 & 0 & 0 & 0 & 0 & 0 & 0 & 0 & 0 & 0 & 0 & 0 \\
\hline F13 & $29.969 \pm 0.090$ & $\mathrm{KAcG}$ & 0 & 0 & 0 & 0 & 0 & 0 & 0 & 0 & 0 & 0 & 0 & 0 & 0 & 0 & 0 & 0 & 0 & 0 & 0 & 0 & 0 & 0 & 0 \\
\hline F14 & $31.610 \pm 0.056$ & KG & 0 & 0 & 0 & 0 & 0 & 0 & 0 & 0 & 0 & 0 & 0 & 0 & 0 & 0 & 0 & 0 & 0 & 0 & 0 & 0 & 0 & 0 & 0 \\
\hline F15 & $31.434 \pm 0.131$ & KG & 1 & 1 & 1 & 1 & 1 & 1 & 1 & 1 & 1 & 1 & 1 & 1 & 1 & 1 & 1 & 1 & 1 & 1 & 1 & 1 & 1 & 1 & 1 \\
\hline F16 & $32.506 \pm 0.126$ & KG & 0 & 0 & 0 & 0 & 0 & 0 & 0 & 0 & 0 & 0 & 0 & 0 & 1 & 0 & 1 & 0 & 0 & 0 & 0 & 0 & 0 & 0 & 0 \\
\hline F17 & $33.238 \pm 0.095$ & 0 & 0 & 0 & 0 & 0 & 0 & 0 & 0 & 0 & 0 & 0 & 0 & 0 & 0 & 0 & 0 & 0 & 0 & 0 & 0 & 0 & 0 & 0 & 0 \\
\hline F18 & $33.609 \pm 0.051$ & KG & 0 & 0 & 0 & 0 & 0 & 0 & 0 & 0 & 0 & 0 & 0 & 0 & 0 & 0 & 0 & 0 & 0 & 0 & 0 & 0 & 0 & 0 & 0 \\
\hline F19 & $34.937 \pm 0.086$ & KRhaG & 0 & 0 & 0 & 0 & 0 & 0 & 0 & 0 & 0 & 0 & 0 & 0 & 0 & 0 & 0 & 0 & 0 & 0 & 0 & 0 & 0 & 0 & 0 \\
\hline F20 & $34.720 \pm 0.00$ & $\mathrm{QA}$ & 0 & 0 & 0 & 0 & 0 & 0 & 0 & 0 & 0 & 0 & 0 & 0 & 0 & 0 & 0 & 0 & 0 & 0 & 0 & 0 & 0 & 0 & 0 \\
\hline F21 & $35.603 \pm 0.154$ & KG & 0 & 0 & 0 & 0 & 0 & 0 & 0 & 0 & 0 & 0 & 0 & 0 & 0 & 0 & 0 & 0 & 0 & 0 & 0 & 0 & 0 & 0 & 0 \\
\hline F22 & $35.445 \pm 0.046$ & KG & 0 & 0 & 0 & 0 & 0 & 0 & 0 & 0 & 0 & 0 & 0 & 0 & 0 & 0 & 0 & 0 & 0 & 0 & 0 & 0 & 0 & 0 & 0 \\
\hline $\mathrm{F} 23$ & $37.148 \pm 0.169$ & KG & 0 & 0 & 0 & 0 & 0 & 0 & 0 & 0 & 0 & 0 & 0 & 0 & 0 & 0 & 0 & 0 & 0 & 0 & 0 & 0 & 0 & 0 & 0 \\
\hline F24 & $38.191 \pm 0.030$ & KRh & 0 & 0 & 0 & 0 & 0 & 0 & 0 & 0 & 0 & 0 & 0 & 0 & 0 & 0 & 0 & 0 & 0 & 0 & 0 & 0 & 0 & 0 & 0 \\
\hline F25 & $37.198 \pm 0.096$ & KG & 1 & 1 & 1 & 1 & 1 & 1 & 1 & 1 & 1 & 1 & 1 & 1 & 1 & 1 & 1 & 1 & 1 & 1 & 1 & 1 & 1 & 1 & 1 \\
\hline F26 & $38.577 \pm 0.236$ & KG & 0 & 0 & 0 & 0 & 0 & 0 & 0 & 0 & 0 & 0 & 0 & 0 & 0 & 0 & 0 & 0 & 0 & 0 & 0 & 0 & 0 & 0 & 0 \\
\hline F27 & $38.874 \pm 0.00$ & 0 & 0 & 0 & 0 & 0 & 0 & 0 & 0 & 0 & 0 & 0 & 0 & 0 & 0 & 0 & 0 & 0 & 0 & 0 & 0 & 0 & 0 & 0 & 0 \\
\hline F28 & $40.004 \pm 0.120$ & 0 & 0 & 0 & 0 & 0 & 0 & 0 & 0 & 0 & 0 & 0 & 0 & 0 & 0 & 0 & 0 & 0 & 0 & 0 & 0 & 0 & 0 & 0 & 0 \\
\hline F29 & $40.074 \pm 0.00$ & KG & 0 & 0 & 0 & 0 & 0 & 0 & 0 & 0 & 0 & 0 & 0 & 0 & 0 & 0 & 0 & 0 & 0 & 0 & 0 & 0 & 0 & 0 & 0 \\
\hline F30 & $40.924 \pm 0.00$ & KG & 0 & 0 & 0 & 0 & 0 & 0 & 0 & 0 & 0 & 0 & 0 & 0 & 0 & 0 & 0 & 0 & 0 & 0 & 0 & 0 & 0 & 0 & 0 \\
\hline F31 & $48.528 \pm 0.057$ & 0 & 0 & 0 & 0 & 0 & 0 & 0 & 0 & 0 & 0 & 0 & 0 & 0 & 0 & 0 & 0 & 0 & 0 & 0 & 0 & 0 & 0 & 0 & 0 \\
\hline F32 & $50.385 \pm 0.161$ & 0 & 0 & 0 & 0 & 0 & 0 & 0 & 0 & 0 & 0 & 0 & 0 & 0 & 0 & 0 & 0 & 0 & 0 & 0 & 0 & 0 & 0 & 0 & 0 \\
\hline
\end{tabular}

*: Mean and standard deviation; KG: Kaempferol Glycoside; QG: Quercetin Glycoside; K3,7OG: Kaempferol-3,7-O-diglucoside; KAcG: Kaempferol-3-O-[6-acetylglucoside]-7-O-glucoside; KRhG: Kaempferol-3-O-[rhamnosyl(1-6) glucoside]; QA: Quercetin-3-O-arabinoside; KRh: Kaempferol-3-O-rhamnoside. 1: Present; 0: Absent

Table 5: Individual distribution of foliar flavonoid compounds of Agave asperrima

\begin{tabular}{|c|c|c|c|c|c|c|c|c|c|c|c|c|c|c|c|c|c|c|c|c|c|c|c|c|c|}
\hline Comp. & $\begin{array}{l}\text { Retention } \\
\text { time (min) }\end{array}$ & $\begin{array}{l}\text { Chem. } \\
\text { Ident. }\end{array}$ & 301 & 302 & 303 & 304 & 305 & 306 & 307 & 308 & 309 & 310 & 311 & 313 & 314 & 315 & 317 & 319 & 320 & 321 & 322 & 323 & 324 & 325 & 326 \\
\hline F1 & $18.227 \pm 0.093$ & KG & 0 & 0 & 0 & 0 & 0 & 0 & 0 & 0 & 0 & 0 & 0 & 0 & 0 & 0 & 0 & 0 & 0 & 0 & 0 & 0 & 0 & 0 & 0 \\
\hline F2 & $18.865 \pm 0.00$ & KG & 0 & 0 & 0 & 0 & 0 & 0 & 0 & 0 & 0 & 0 & 0 & 0 & 0 & 0 & 0 & 0 & 0 & 0 & 0 & 0 & 0 & 0 & 0 \\
\hline F3 & $19.598 \pm 0.035$ & KG & 0 & 0 & 0 & 0 & 0 & 0 & 0 & 0 & 0 & 0 & 0 & 0 & 0 & 0 & 0 & 0 & 0 & 0 & 0 & 0 & 0 & 0 & 0 \\
\hline F4 & $22.489 \pm 0.042$ & KG & 0 & 0 & 0 & 0 & 0 & 0 & 0 & 0 & 0 & 0 & 0 & 0 & 0 & 0 & 0 & 0 & 0 & 0 & 0 & 0 & 0 & 0 & 0 \\
\hline F5 & $23.326 \pm 0.089$ & KG & 0 & 0 & 0 & 0 & 0 & 0 & 0 & 0 & 0 & 0 & 0 & 0 & 0 & 0 & 0 & 0 & 0 & 0 & 0 & 0 & 0 & 0 & 0 \\
\hline F6 & $24.438 \pm 0.00$ & KG & 0 & 0 & 0 & 0 & 0 & 0 & 0 & 0 & 0 & 0 & 0 & 0 & 0 & 0 & 0 & 0 & 0 & 0 & 0 & 0 & 0 & 0 & 0 \\
\hline F7 & $25.142 \pm 0.00$ & QG & 0 & 0 & 0 & 0 & 0 & 0 & 0 & 0 & 0 & 0 & 0 & 0 & 0 & 0 & 0 & 0 & 0 & 0 & 0 & 0 & 0 & 0 & 0 \\
\hline F8 & $27.067 \pm 0.00$ & QG & 0 & 0 & 0 & 0 & 0 & 0 & 0 & 0 & 0 & 0 & 0 & 0 & 0 & 0 & 0 & 0 & 0 & 0 & 0 & 0 & 0 & 0 & 0 \\
\hline F9 & $27.710 \pm 0.060$ & KG & 0 & 0 & 0 & 0 & 0 & 0 & 0 & 0 & 0 & 0 & 0 & 0 & 0 & 0 & 0 & 0 & 0 & 0 & 0 & 0 & 0 & 0 & 0 \\
\hline F10 & $28.313 \pm 0.014$ & KG & 0 & 0 & 0 & 0 & 0 & 0 & 0 & 0 & 0 & 0 & 0 & 0 & 0 & 0 & 0 & 0 & 0 & 0 & 0 & 0 & 0 & 0 & 0 \\
\hline F11 & $27.623 \pm 0.051$ & $\mathrm{~K} 3,7 \mathrm{OG}$ & 0 & 0 & 0 & 0 & 0 & 0 & 0 & 0 & 0 & 0 & 0 & 0 & 0 & 0 & 0 & 0 & 0 & 0 & 0 & 0 & 0 & 0 & 0 \\
\hline F12 & $29.955 \pm 0.104$ & KG & 0 & 0 & 0 & 0 & 0 & 0 & 0 & 0 & 0 & 0 & 0 & 0 & 0 & 0 & 0 & 0 & 0 & 0 & 0 & 0 & 0 & 0 & 0 \\
\hline F13 & $29.969 \pm 0.090$ & $\mathrm{KAcG}$ & 0 & 0 & 0 & 0 & 0 & 0 & 0 & 0 & 0 & 0 & 0 & 0 & 0 & 0 & 0 & 0 & 0 & 0 & 0 & 0 & 0 & 0 & 0 \\
\hline F14 & $31.610 \pm 0.056$ & $\mathrm{KG}$ & 0 & 0 & 0 & 0 & 0 & 0 & 0 & 0 & 0 & 0 & 0 & 0 & 0 & 0 & 0 & 0 & 0 & 0 & 0 & 0 & 0 & 0 & 0 \\
\hline F15 & $31.434 \pm 0.131$ & KG & 1 & 1 & 1 & 1 & 1 & 1 & 1 & 1 & 1 & 1 & 1 & 1 & 1 & 1 & 1 & 1 & 1 & 1 & 1 & 1 & 1 & 1 & 1 \\
\hline F16 & $32.506 \pm 0.126$ & KG & 0 & 0 & 0 & 0 & 0 & 0 & 0 & 0 & 0 & 0 & 0 & 0 & 0 & 0 & 0 & 0 & 0 & 0 & 0 & 0 & 0 & 0 & 0 \\
\hline F17 & $33.238 \pm 0.095$ & KG & 0 & 0 & 0 & 0 & 0 & 0 & 0 & 0 & 0 & 0 & 0 & 0 & 0 & 0 & 0 & 0 & 0 & 0 & 0 & 0 & 0 & 0 & 0 \\
\hline F18 & $33.609 \pm 0.051$ & KG & 0 & 0 & 0 & 0 & 0 & 0 & 0 & 0 & 0 & 0 & 0 & 0 & 0 & 0 & 0 & 0 & 0 & 0 & 0 & 0 & 0 & 0 & 0 \\
\hline F19 & $34.937 \pm 0.086$ & KRhG & 0 & 0 & 0 & 0 & 0 & 0 & 0 & 0 & 0 & 0 & 0 & 0 & 0 & 0 & 0 & 0 & 0 & 0 & 0 & 0 & 0 & 0 & 0 \\
\hline F20 & $34.720 \pm 0.00$ & QA & 0 & 0 & 0 & 0 & 0 & 0 & 0 & 0 & 0 & 0 & 0 & 0 & 0 & 0 & 0 & 0 & 0 & 0 & 0 & 0 & 0 & 0 & 0 \\
\hline F21 & $35.603 \pm 0.154$ & KG & 0 & 0 & 0 & 0 & 0 & 0 & 0 & 0 & 0 & 0 & 0 & 0 & 0 & 0 & 0 & 0 & 0 & 0 & 0 & 0 & 0 & 0 & 0 \\
\hline F22 & $35.445 \pm 0.046$ & KG & 0 & 0 & 0 & 0 & 0 & 0 & 0 & 0 & 0 & 0 & 0 & 0 & 0 & 0 & 0 & 0 & 0 & 0 & 0 & 0 & 0 & 0 & 0 \\
\hline F 23 & $37.148 \pm 0.169$ & KG & 0 & 0 & 0 & 1 & 0 & 0 & 0 & 0 & 1 & 0 & 0 & 0 & 1 & 1 & 0 & 0 & 1 & 1 & 1 & 0 & 1 & 1 & 1 \\
\hline F24 & $38.191 \pm 0.030$ & $\mathrm{KRh}$ & 0 & 0 & 0 & 0 & 0 & 0 & 0 & 0 & 0 & 0 & 0 & 0 & 0 & 0 & 0 & 0 & 0 & 0 & 0 & 0 & 0 & 0 & 0 \\
\hline F25 & $37.198 \pm 0.096$ & $\mathrm{KG}$ & 0 & 0 & 0 & 0 & 0 & 0 & 0 & 0 & 0 & 0 & 0 & 0 & 0 & 0 & 0 & 0 & 0 & 0 & 0 & 0 & 0 & 0 & 0 \\
\hline F26 & $38.577 \pm 0.236$ & KG & 0 & 0 & 0 & 0 & 0 & 0 & 0 & 0 & 0 & 0 & 0 & 0 & 0 & 0 & 0 & 0 & 0 & 0 & 0 & 0 & 0 & 0 & 0 \\
\hline F27 & $38.874 \pm 0.00$ & KG & 0 & 0 & 1 & 0 & 1 & 0 & 0 & 0 & 0 & 0 & 0 & 0 & 0 & 0 & 0 & 0 & 0 & 0 & 0 & 0 & 0 & 0 & 0 \\
\hline
\end{tabular}


Am. J. Applied Sci., 6 (6): 1076-1085, 2009

Table 5: Continued

\begin{tabular}{llllllllllllllllllllllllllllllll}
\hline F28 & $40.004 \pm 0.120$ & KG & 0 & 0 & 0 & 0 & 0 & 0 & 0 & 0 & 0 & 0 & 0 & 0 & 0 & 0 & 0 & 0 & 0 & 0 & 0 & 0 & 0 & 0 & 0 \\
F29 & $40.074 \pm 0.00$ & KG & 0 & 0 & 0 & 0 & 0 & 0 & 0 & 0 & 0 & 0 & 0 & 0 & 0 & 0 & 0 & 0 & 0 & 0 & 0 & 0 & 0 & 0 & 0 & 0 \\
F30 & $40.924 \pm 0.00$ & KG & 0 & 0 & 0 & 0 & 0 & 0 & 0 & 0 & 0 & 0 & 0 & 0 & 0 & 0 & 0 & 0 & 0 & 0 & 0 & 0 & 0 & 0 & 0 \\
F31 & $48.528 \pm 0.057$ & KG & 0 & 0 & 0 & 0 & 0 & 0 & 0 & 0 & 0 & 0 & 0 & 0 & 0 & 0 & 0 & 0 & 0 & 0 & 0 & 0 & 0 & 0 & 0 \\
F32 & $50.385 \pm 0.161$ & KG & 0 & 0 & 0 & 0 & 0 & 0 & 0 & 0 & 0 & 0 & 0 & 0 & 0 & 0 & 0 & 0 & 0 & 0 & 0 & 0 & 0 & 0 & 0 \\
\hline
\end{tabular}

*: Mean and standard deviation; KG: Kaempferol Glycoside; QG: Quercetin Glycoside; K3,7OG: Kaempferol-3,7-O-diglucoside; KAcG: Kaempferol-3-O-[6-acetylglucoside]-7-O-glucoside; KRhG: Kaempferol-3-O-[rhamnosyl(1-6) glucoside]; QA: Quercetin-3-O-arabinoside; KRh: Kaempferol-3-O-rhamnoside

Table 6: Individual distribution of flavonoid compounds of

\begin{tabular}{|c|c|c|c|c|c|c|}
\hline Comp. & $\begin{array}{l}\text { Retention } \\
\text { time }(\mathrm{min})\end{array}$ & $\begin{array}{l}\text { Chem. } \\
\text { ident. }\end{array}$ & Dsy1 & Dsy2 & Dsy3 & Dsy4 \\
\hline $\mathrm{F} 1$ & $18.227 \pm 0.093$ & $\mathrm{KG}$ & 0 & 0 & 0 & 0 \\
\hline $\mathrm{F} 2$ & $18.865 \pm 0.00$ & $\mathrm{KG}$ & 0 & 0 & 0 & 0 \\
\hline F3 & $19.598 \pm 0.035$ & $\mathrm{KG}$ & 0 & 0 & 0 & 0 \\
\hline $\mathrm{F} 4$ & $22.489 \pm 0.042$ & $\mathrm{KG}$ & 0 & 0 & 0 & 0 \\
\hline F5 & $23.326 \pm 0.089$ & $\mathrm{KG}$ & 0 & 0 & 0 & 0 \\
\hline F6 & $24.438 \pm 0.00$ & $\mathrm{KG}$ & 0 & 0 & 0 & 0 \\
\hline F7 & $25.142 \pm 0.00$ & QG & 0 & 0 & 0 & 0 \\
\hline F8 & $27.067 \pm 0.00$ & QG & 0 & 0 & 0 & 0 \\
\hline F9 & $27.710 \pm 0.060$ & $\mathrm{KG}$ & 0 & 0 & 0 & 0 \\
\hline $\mathrm{F} 10$ & $28.313 \pm 0.014$ & $\mathrm{KG}$ & 0 & 0 & 0 & 0 \\
\hline $\mathrm{F} 11$ & $27.623 \pm 0.051$ & $\mathrm{~K} 3,7 \mathrm{OG}$ & 0 & 0 & 0 & 0 \\
\hline F12 & $29.955 \pm 0.104$ & $\mathrm{KG}$ & 1 & 1 & 1 & 1 \\
\hline F13 & $29.969 \pm 0.090$ & KAcG & 0 & 0 & 0 & 0 \\
\hline F14 & $31.610 \pm 0.056$ & $\mathrm{KG}$ & 1 & 1 & 1 & 1 \\
\hline $\mathrm{F} 15$ & $31.434 \pm 0.131$ & KG & 0 & 0 & 0 & 0 \\
\hline F16 & $32.506 \pm 0.126$ & $\mathrm{KG}$ & 0 & 0 & 0 & 0 \\
\hline $\mathrm{F} 17$ & $33.238 \pm 0.095$ & 0 & 1 & 1 & 1 & 1 \\
\hline F18 & $33.609 \pm 0.051$ & $\mathrm{KG}$ & 0 & 0 & 0 & 0 \\
\hline F19 & $34.937 \pm 0.086$ & KRhaG & 0 & 0 & 0 & 0 \\
\hline F20 & $34.720 \pm 0.00$ & QA & 0 & 0 & 0 & 0 \\
\hline $\mathrm{F} 21$ & $35.603 \pm 0.154$ & KG & 1 & 1 & 1 & 1 \\
\hline $\mathrm{F} 22$ & $35.445 \pm 0.046$ & $\mathrm{KG}$ & 0 & 0 & 0 & 0 \\
\hline $\mathrm{F} 23$ & $37.148 \pm 0.169$ & $\mathrm{KG}$ & 0 & 0 & 0 & 0 \\
\hline $\mathrm{F} 24$ & $38.191 \pm 0.030$ & $\mathrm{KRh}$ & 0 & 0 & 0 & 0 \\
\hline $\mathrm{F} 25$ & $37.198 \pm 0.096$ & $\mathrm{KG}$ & 0 & 0 & 0 & 0 \\
\hline F26 & $38.577 \pm 0.236$ & $\mathrm{KG}$ & 0 & 0 & 0 & 0 \\
\hline $\mathrm{F} 27$ & $38.874 \pm 0.00$ & 0 & 0 & 0 & 0 & 0 \\
\hline F28 & $40.004 \pm 0.120$ & 0 & 1 & 1 & 1 & 1 \\
\hline F29 & $40.074 \pm 0.00$ & KG & 0 & 0 & 0 & 0 \\
\hline F30 & $40.924 \pm 0.00$ & $\mathrm{KG}$ & 0 & 0 & 0 & 0 \\
\hline F31 & $48.528 \pm 0.057$ & 0 & 1 & 1 & 1 & 1 \\
\hline F32 & $50.385 \pm 0.161$ & 0 & 1 & 1 & 1 & 1 \\
\hline
\end{tabular}

*: Mean and standard deviation; KG: Kaempferol Glycoside; QG: Quercetin Glycoside; K3,7OG: Kaempferol-3,7-O-diglucoside; KAcG: Kaempferol-3-O-[6-acetylglucoside]-7-O-glucoside; KRhG: Kaempferol-3-O-[rhamnosyl(1-6) glucoside]; QA: Quercetin-3-Oarabinoside; KRh: Kaempferol-3-O-rhamnoside. 1: Present; 0: Absent

The foliar phenol profiles of all individuals identified, on a morphological basis, as Agave asperrima (samples 300-333) showed a very simple foliar phenol profile. The individual profiles were very homogeneous. The patterns were formed for only one or two among three different kaempferol glycosides (Table 5). The PCO analysis clearly separates the samples of A. asperrima from all the other individuals (Fig. 1).

None kaempferol glycoside derivative was found as part of foliar phenol profile of Dasylirion sp., but one quercetin glycoside, one luteolin glycoside, probably one gossypetin glycoside and four unidentified flavones glycosides were detected (Table 6).

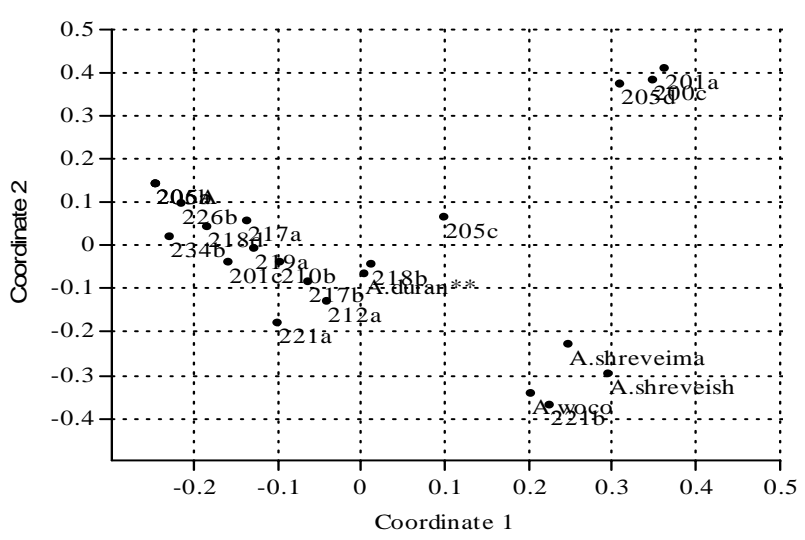

Fig. 2: Results of Principal Coordinates Analysis comparing foliar flavonoid profiles for juvenile samples of Agave durangensis from Sierra de Registro (200c-234b), Agave durangensis from Botanico Garden, UNAM (A. duran**), A. shrevei subsp. shrevei (A. shrevei sh), A. shrevei subsp. matapensis (A. shrevei ma) and A. wocomahi (A. woco)

The PCO analysis place Dasylirion sp., which belongs to family Nolinaceae ${ }^{[9]}$, clearly separated from Agave (Fig. 1).

The foliar phenol profiles of juvenile samples of Agave durangensis were more complex and variable than those belonging to adults (Table 7). A total of 28 different kaempferol glycosides were found and from three to eleven could be present in any sample. Compounds J10, J14 and J22 (Table 7) are shared with adults. However, a considerable difference exists between juvenile and adult profiles. This difference suggests that, contrary to reported for others species of plants by Abou-Zaid and Nozzolillo ${ }^{[36]}$ and AlmarazAbarca et $a l .{ }^{[15]}$, who did not find any age-related variability in foliar flavonoid composition, the qualitative expression of $A$. durangensis foliar flavonoids is not defined from the juvenile stage. The role of all these compounds in the growth and development processes of this species is left for determining.

The phenol foliar profile of juvenile sample of A. durangensis donated by the Botanic Garden, UNAM, was formed by four kaempferol glycoside derivatives, 
Am. J. Applied Sci., 6 (6): 1076-1085, 2009

Table 7: Individual distribution of flavonoid compounds of juvenile plants of Agave durangensis, A. shrevei subsp. shrevei, A. shrevei subsp. matapensis, and A. wocomah

\begin{tabular}{|c|c|c|c|c|c|c|c|c|c|c|c|c|c|c|c|c|c|c|c|c|c|c|c|c|c|}
\hline & $\begin{array}{l}\text { Retention } \\
\text { time } \\
(\mathrm{min})^{*}\end{array}$ & $\begin{array}{l}\text { Chem. } \\
\text { Ident. }\end{array}$ & $200 c$ & $201 \mathrm{a}$ & $201 \mathrm{c}$ & $205 \mathrm{a}$ & $205 \mathrm{~b}$ & $205 c$ & $205 d$ & $206 \mathrm{a}$ & $210 \mathrm{~b}$ & $212 a$ & $217 \mathrm{a}$ & $217 \mathrm{~b}$ & $218 b$ & $218 \mathrm{~d}$ & $219 a$ & $221 \mathrm{a}$ & $221 b$ & $226 \mathrm{~b}$ & $234 \mathrm{~b}$ & $\begin{array}{l}\text { A. } \\
\text { duran** }^{*}\end{array}$ & $\begin{array}{l}\text { A. } \\
\text { shrevei } \\
\text { sh }\end{array}$ & $\begin{array}{l}\text { A. } \\
\text { shrevei } \\
\text { ma }\end{array}$ & $\begin{array}{l}\text { A. } \\
\text { woco }\end{array}$ \\
\hline $\mathrm{J} 1$ & $13.216 \pm 0.00$ & KG & 1 & 0 & 0 & 0 & 0 & 0 & 0 & 0 & 0 & 0 & 0 & 0 & 0 & 0 & 0 & 0 & 0 & 0 & 0 & 0 & 0 & 0 & 0 \\
\hline $\mathrm{J} 2$ & $15.857 \pm 0.098$ & KG & 1 & 1 & 0 & 0 & 0 & 0 & 1 & 0 & 0 & 0 & 0 & 0 & 0 & 0 & 0 & 0 & 0 & 0 & 0 & 0 & 0 & 0 & 0 \\
\hline $\mathrm{J} 3$ & $17.126 \pm 0.069$ & KG & 1 & 1 & 0 & 0 & 0 & 0 & 1 & 0 & 0 & 0 & 0 & 0 & 0 & 0 & 0 & 0 & 0 & 0 & 0 & 0 & 0 & 0 & 0 \\
\hline $\mathrm{J} 4$ & $20.214 \pm 0.00$ & KG & 0 & 1 & 0 & 0 & 0 & 0 & 0 & 0 & 0 & 0 & 0 & 0 & 0 & 0 & 0 & 0 & 0 & 0 & 0 & 0 & 0 & 0 & 0 \\
\hline J5 & $21.353 \pm 0.132$ & KG & 1 & 1 & 0 & 0 & 0 & 0 & 0 & 0 & 0 & 0 & 0 & 0 & 1 & 0 & 0 & 0 & 0 & 0 & 0 & 0 & 0 & 0 & 0 \\
\hline J6 & $21.838 \pm 0.084$ & KG & 0 & 1 & 0 & 0 & 0 & 0 & 1 & 0 & 0 & 0 & 0 & 0 & 0 & 0 & 0 & 0 & 0 & 0 & 0 & 0 & 0 & 0 & 0 \\
\hline $\mathrm{J} 7$ & $24.585 \pm 0.00$ & KG & 0 & 0 & 0 & 0 & 0 & 0 & 0 & 0 & 0 & 0 & 0 & 0 & 0 & 0 & 0 & 0 & 0 & 0 & 0 & 0 & 0 & 1 & 0 \\
\hline J8 & $27.108 \pm 0.79$ & KG & 0 & 0 & 0 & 0 & 0 & 0 & 0 & 0 & 0 & 1 & 0 & 1 & 1 & 0 & 0 & 0 & 1 & 0 & 0 & 0 & 0 & 0 & 1 \\
\hline J9 & $28.149 \pm 0.110$ & KG & 0 & 0 & 0 & 0 & 0 & 0 & 0 & 0 & 0 & 1 & 0 & 1 & 0 & 0 & 0 & 1 & 1 & 0 & 0 & 0 & 1 & 1 & 1 \\
\hline $\mathrm{J} 10$ & $27.704 \pm 0.040$ & $\begin{array}{l}\text { K3, } \\
7 \mathrm{OG}\end{array}$ & 0 & 0 & 1 & 1 & 1 & 0 & 0 & 1 & 0 & 1 & 1 & 1 & 1 & 1 & 1 & 1 & 0 & 1 & 1 & 0 & 0 & 0 & 0 \\
\hline $\mathrm{J} 11$ & $29.352 \pm 0.00$ & KG & 0 & 0 & 0 & 0 & 0 & 0 & 0 & 0 & 1 & 0 & 0 & 0 & 0 & 0 & 0 & 0 & 0 & 0 & 0 & 0 & 0 & 0 & 0 \\
\hline $\mathrm{J} 12$ & $30.892 \pm 0.088$ & KG & 0 & 0 & 1 & 0 & 0 & 1 & 0 & 0 & 0 & 1 & 0 & 0 & 1 & 0 & 0 & 0 & 1 & 0 & 0 & 1 & 1 & 0 & 0 \\
\hline $\mathrm{J} 13$ & $30.965 \pm 0.00$ & KG & 0 & 0 & 0 & 0 & 0 & 0 & 0 & 0 & 0 & 0 & 0 & 0 & 0 & 0 & 0 & 0 & 0 & 0 & 0 & 0 & 0 & 0 & 1 \\
\hline $\mathrm{J} 14$ & $31.624 \pm 0.027$ & KG & 0 & 0 & 1 & 1 & 1 & 0 & 0 & 1 & 1 & 1 & 1 & 1 & 1 & 1 & 1 & 1 & 0 & 1 & 1 & 1 & 0 & 0 & 0 \\
\hline $\mathrm{J} 15$ & $32.983 \pm 0.31$ & KG & 0 & 0 & 1 & 0 & 0 & 0 & 0 & 0 & 1 & 1 & 1 & 1 & 0 & 1 & 1 & 1 & 1 & 0 & 1 & 0 & 0 & 0 & 1 \\
\hline J16 & $34.060 \pm 0.044$ & KG & 0 & 0 & 0 & 0 & 0 & 0 & 0 & 0 & 0 & 0 & 0 & 0 & 1 & 0 & 1 & 0 & 0 & 1 & 0 & 1 & 0 & 1 & 0 \\
\hline $\mathrm{J} 17$ & $35.064 \pm 0.032$ & KG & 0 & 0 & 1 & 0 & 0 & 0 & 0 & 0 & 0 & 0 & 0 & 1 & 0 & 1 & 0 & 0 & 0 & 0 & 0 & 1 & 0 & 0 & 0 \\
\hline $\mathrm{J} 18$ & $35.911 \pm 0.054$ & KG & 0 & 0 & 0 & 0 & 0 & 1 & 0 & 0 & 0 & 0 & 1 & 0 & 1 & 0 & 0 & 0 & 1 & 0 & 0 & 0 & 0 & 0 & 0 \\
\hline J19 & $36.685 \pm 0.00$ & FG & 0 & 0 & 0 & 0 & 0 & 0 & 0 & 0 & 0 & 0 & 0 & 0 & 0 & 0 & 0 & 0 & 0 & 0 & 0 & 0 & 1 & 0 & 0 \\
\hline $\mathrm{J} 20$ & $36.806 \pm 0.138$ & KG & 0 & 0 & 0 & 0 & 0 & 0 & 0 & 0 & 0 & 1 & 1 & 1 & 1 & 1 & 1 & 1 & 0 & 0 & 0 & 0 & 0 & 0 & 0 \\
\hline $\mathrm{J} 21$ & $36.011 \pm 0.00$ & $\begin{array}{l}\text { K3- } \\
\text { OG }\end{array}$ & 0 & 0 & 1 & 0 & 0 & 0 & 0 & 0 & 0 & 0 & 0 & 0 & 0 & 0 & 0 & 0 & 0 & 0 & 0 & 0 & 0 & 0 & 0 \\
\hline $\mathrm{J} 22$ & $38.269 \pm 0.080$ & $\mathrm{KRh}$ & 0 & 0 & 1 & 1 & 1 & 1 & 0 & 1 & 0 & 1 & 1 & 1 & 0 & 1 & 0 & 0 & 0 & 1 & 1 & 0 & 0 & 0 & 0 \\
\hline $\mathrm{J} 23$ & $37.466 \pm 0.00$ & FG & 1 & 0 & 0 & 0 & 0 & 0 & 0 & 0 & 0 & 0 & 0 & 0 & 0 & 0 & 0 & 0 & 0 & 0 & 0 & 0 & 0 & 0 & 0 \\
\hline $\mathrm{J} 24$ & $37.838 \pm 0.047$ & KG & 0 & 0 & 0 & 0 & 0 & 0 & 1 & 0 & 0 & 1 & 1 & 1 & 0 & 1 & 0 & 0 & 0 & 0 & 0 & 0 & 0 & 0 & 0 \\
\hline $\mathrm{J} 25$ & $38.461 \pm 0.133$ & KG & 0 & 0 & 0 & 0 & 0 & 1 & 1 & 0 & 0 & 1 & 1 & 0 & 0 & 0 & 1 & 0 & 0 & 0 & 0 & 0 & 0 & 0 & 0 \\
\hline $\mathrm{J} 26$ & $40.620 \pm 0.054$ & KG & 0 & 0 & 1 & 0 & 0 & 0 & 0 & 0 & 1 & 0 & 0 & 0 & 0 & 0 & 1 & 0 & 0 & 1 & 0 & 0 & 0 & 0 & 0 \\
\hline $\mathrm{J} 27$ & $42.191 \pm 0.094$ & KG & 0 & 0 & 0 & 0 & 0 & 1 & 1 & 0 & 0 & 0 & 0 & 1 & 0 & 0 & 0 & 0 & 0 & 0 & 0 & 0 & 0 & 0 & 0 \\
\hline \multirow[t]{2}{*}{$\mathrm{J} 28$} & $43.622 \pm 0.132$ & KG & 0 & 0 & 0 & 0 & 0 & 0 & 0 & 0 & 0 & 0 & 1 & 1 & 0 & 1 & 0 & 0 & 0 & 0 & 0 & 0 & 0 & 0 & 0 \\
\hline & & Total & 5 & 5 & 8 & 3 & 3 & 5 & 6 & 3 & 4 & 10 & 9 & 11 & 8 & 8 & 7 & 5 & 5 & 5 & 4 & 4 & 3 & 3 & 4 \\
\hline
\end{tabular}

*: Mean and standard deviation; **: Sample donated by Jordan Botánico UNAM; KG: Kaempferol Glycoside; K3, 7OG: Kaempferol-3,7-Odiglucoside; K3-OG: KRh: Kaempferol-3-O-rhamnoside. 1: Present; 0: Absent

all also present in the juvenile samples of $A$. durangensis collected and analyzed (Table 7). That donated sample is situated among most of the A. durangensis samples collected from Sierra of Registro by the PCO analysis. Other three groups are distinguished, each formed by one to three individuals; these groups could represent different chemotypes (Fig. 2).

Agave wocomahi, which belongs to the same section Ditepalae than Agave durangensis ${ }^{[3]}$, showed profiles formed by four kaempferol derivatives (J8, J9, $\mathrm{J} 13$ and $\mathrm{J} 15)$, all, except $\mathrm{J} 13$, are also present in juvenile A. durangensis samples (Table 7). The PCO analysis places this species close to the juvenile sample $221 \mathrm{~b}$ of $A$. durangensis.

Concerning to the foliar phenol profile of $A$. shrevei subsp. shrevei and A. shrevei subsp. matapensis (belonging also to the same section Ditepalae), their profiles were different to that of $A$. wocomahi and that of A. durangensis. They were formed by three kaempferol glycoside derivative, from which one (J9) was common to both (Table 7). The PCO analysis of foliar profiles of juvenile samples groups together both subspecies of $A$. shrevei (Fig. 2).

\section{CONCLUSION}

The foliar and pollen phenol compositions of Agave durangensis are rich in glycosides derivatives of the flavonol kaempferol. Actually, this kind of compounds domain in all species of Agave studied. These taxa could be distinguished by the foliar phenol components and some species-specific patterns could be discerned. This reveals the flavonoid foliar profiles as valuable specific chemical markers in Agave.

In spite of the intrapopulation variability detected within the population of Agave durangensis from Sierra of Registro, the presence of specific flavonoid components in the leaves of each analyzed population (Sierra of Registro and "Temoaya") suggest the recognition of two independent taxonomic entities within this morphologically variable group.

\section{ACKNOWLEDGMENT}

Thanks are given to CONACYT for the support (60664-CB-2006-1) provided to this research and to COFAA for the grant given to some of the authors.

\section{REFERENCES}

1. Good-Ávila, S.V., V. Souza, B.S. Gaut and L.E. Eguiarte, 2006. Timing and rate of speciation in Agave (Agavaceae). Proc. Natl. Acad. USA., 103: 9124-9129. DOI: 10.1073/pnas.0603312103 
2. Rocha, M., S.V. Good-Ávila, F. Molina-Freaner, H.T. Arita, A. Castillo, A. García-Mendoza, A. Silva-Montellano, B.S. Gaut, V. Souza and L.E. Eguiarte, 2006. Pollination biology and adaptive radiation of Agavaceae, with special emphasis on the genus Agave. Aliso, 22: 329-344. http://cat.inist.fr/?aModele=afficheN\&cpsidt $=18269730$

3. Gentry, H.S., 1982. Agaves of Continental North America. The University of Arizona Press. Tucson, ISBN: 0-8165-0775-9, pp: 670.

4. Granados-Sánchez, D., 1999. The Agaves in Mexico. Autonomous University of Chapingo, Chapingo, México, ISBN: 968-884-225-7, pp: 252.

5. Colunga-GarcíaMarín, P., A.S. Larqué, L.E. Eguiarte and D. ZizumboVillarreal, 2007. Introduction. In: In the Ancestral there is Futur. Scientific Research Center of Yucatán, México, pp: 5-12.

6. Colunga-GarcíaMarín, P. and D. Zizumbo-Villarreal, 2007. Tequila and other Mescales from CentralWestern Mexico: Domestication, Diversity and Conservation of Germoplasm. In: In the Ancestral there is Futur. Scientific Research Center of Yucatán, Mexico, pp: 402.

7. Valenzuela-Ruíz, J.F., O.H. Velasco-González and M.A. Márquez-Linares, 2003. Sustanaible Development of Agave Mezcalero in Durango. SEP, CIIDIR-IPN-Dgo., SAGDR. México, ISBN: P70-93232-2-9, pp: 208.

8. López, G.M., N.A. Mancilla-Margalli and G. Mendoza-Diaz, 2003. Molecular structures of fructans from Agave tequilana weber var. azul. J. Agric. Food Chem., 51: 7835-7840. DOI: 10.1021/jf030383v

9. García-Mendoza, A. and R. Galván, 1995. Richness of Families Agavaceae and Nolinaceae in Mexico. Boletín de la Sociedad Botánica de México, 56: 7-24. ISSN: 0366-2128.

10. González-Elizondo, M., R. Galván- Villaneva, I.L. López-Enriquez, L.R. Reséndiz and M.S. González-Elizondo, 2009. Agaves. Magueyes, Lechuguillas and Noas of Durango Estate and its Surrounings. IPN-CONABIO, Mexico,

11. Markham, K.R. and M.G. Campos, 1996. 7- and 8O-methylherbacetin-3-O-sophorosides from bee pollens and some structure/activity observation. Phytochemistry, 43: 763-767. DOI: 10.1016/00319422(96)00286-5

12. Almaraz-Abarca, N., M.G. Campos, E.A. DelgadoAlvarado, J.A. Ávila-Reyes, J. Herrera-Corral, L.S. González-Valdez, N. Naranjo-Jiménez, C. Frigeirio, A.F. Tomatas, A.J. Almeida and J.N. Uribe-Soto, 2008. Pollen flavonoi/phenolic acid composition of four species of Cactaceae and its taxonomic significance. Am. J. Agric. Biol. Sci., 3: 532-543. http://nsdl.org/resource/2200/20080911201055428T
13. Bate-Smith, E.C., I.K. Ferguson, K. Hutson, S.R. Jensen, B.J. Nielsen and T. Swain, 1975. Phytochemical interrelationships in the Cornaceae. Biochem. Syst. Ecol., 3: 79-89. DOI: 10.1016/0305-1978(75)90046-0

14. Del Pero, M.M.A., J.P. Pelotto and N. Basualdo, 1997. Distribution of flavonoid aglycones in Ilex Species (A. quifoliaceae). Biochem. Syst. Ecol., 25: 619-622. DOI: 10.1016/S03051978(97)000549

15. Almaraz-Abarca, N., M.S. González-Elizondo, J.A. Tena-Flores, J.A. Ávila-Reyes, J. Herrera-Corral and N. Naranjo Jiménez, 2006. Foliar flavonoids distinguish Pinus leiophylla and Pinus chihuahuana (Coniferales: Pinaceae). Proc. Biol Soc. Washington, 119: 426-436.

http://apt.allenpress.com/perlserv/?request=getabstract\&doi $=10.2988 \% 2$ F0006324X(2006)119\%5B426\%3AFFDPLA\%5D2.0.CO $\% 3 \mathrm{~B} 2 \& \mathrm{ct}=1$

16. Campos, M., K.R. Markham, K.A. Mitchell and A. Proença da Cunha, 1997. An approach to the characterization of bee pollens via their flavonoid/phenolic profiles. Phytochem. Anal., 8: 181-185. DOI: $10.1002 /(\mathrm{SICI}) 1099-$ 1565(199707)8:4<181::AID-PCA359>3.0.CO;2-A

17. Almaraz-Abarca, N., M.G. Campos, J.A. ÁvilaReyes, N. Naranjo-Jiménez, J. Herrera-Corral and L.S. González-Valdez, 2004. Variability of antioxidant activity among honeybee-collected pollen of different botanical origin. Interciencia, 29: 574-578.

http://www.scielo.org.ve/scielo.php?pid=S0378$18442004001000006 \&$ script=sci_arttext

18. Fukai, T., C.B. Shen, T. Horikoshi and T. Nomura, 1996. Isoprenilated flavonoids from underground parts of Glycyrrhiza glabra. Phytochemistry, 43: 1119-1124. DOI: 10.1016/S0031-9422(96)00391-3

19. Grayer, R.J., S.E. Bryan, N.C. Veitch, F.J. Goldstone, A. Paton and E. Wollenweber, 1996. External flavones in sweet basil, Ocimum basilicum and related taxa. Phytochemistry, 43: 1041-1047. DOI: 10.1016/S0031-9422(96)00430-X

20. Morales, M.A., 1972. Steroidal sapogenins from agave cocui. Phytochemistry, 1: 1191-1192. DOI: 10.1016/S0031-9422(00)88496-4

21. Wilkomirski, B., V.A. Bobeyko and P.K. Kintia, 1975. New steroidal saponins of Agave americana. Phytochemistry, 14: 2657-2659. DOI: 10.1016/0031-9422(75)85245-9

22. Blunden, G., Y. Yi and K. Jewers, 1978. Steroidal sapogenins from leaves of Agaveae species. Phytochemistry, 17: 1923-1925. DOI: 10.1016/S0031-9422(00)88734-8 
23. Uniyal, G.C., P.K. Agrawal, O.P. Sati and R.S. Thaker, 1991. Agaveside C, a steroidal glycoside from Agave cantala. Phytochemistry, 30: 13361339. DOI: 10.1016/S0031-9422(00)95232-4

24. Parmar, V.S., H.N. Jha, A.K. Gupta and A.K. Prasad, 1992. Phytochemistry, 31: 2567-2568. DOI: 10.1016/0031-9422(92)83333-T

25. Subramanian, S.S. and A.G.R. Nair, 1970. Chlorogenein and kaempferol glycosides from the flowers of agave Americana. Phytochemistry, 9: 2582. DOI: 10.1016/S0031-9422(00)85782-9

26. Mabry, T.J., K.R. Markham and M.B. Thomas, 1970. The Systematic Identification of Flavonoids. 1st Edn., Springer-Verlag, New York, pp: 354.

27. Campos, M.G. and K.R. Markham, 2007. Structure Information from HPLC and On-Line Measured Absorption Spectra: Flavones, Flavonols and Phenolic Acids. University of Coimbra, Portugal, ISBN: 978-989-8074-05-8, pp: 118.

28. Rohlf, F.J. 1993. NTSyS-PC. Numerical Taxonomy and Multivariate Analysis System. Version 1.8. Applied Biostatistics Inc., New York.

29. Almaraz-Abarca, N., M.G. Campos, A. DelgadoAlvarado, J.A. Ávila-Reyes, N. Naranjo-Jiménez, J. Herre-Corral, A.F. Tomatas, A.J. Almeida and A. Vieira, 2007. Pollen phenols of Stenocactus, Echinicereus and Mammillaria (Cactaceae). Polibotánica, 23: 37-55.

30. Ylstra, B., T. Alisher, M.R.M. Benito, E. Stöger, A.J. van Tunen, O. Vicente, J.N.M. Mol and E. Heberle-Bors, 1992. Flavonols stimulate development, germination and tube growth of tobacco pollen. Plant Physiol., 100: 902-907. http://www.ncbi.nlm.nih.gov/pubmed/16653074
31. Mo, Y., C. Ángel and L.P. Taylor, 1992. Biochemical complementation of chalcone synthase mutants defines a role for flavonols in functional pollen. Proc. Natl. Acad. Sci. USA., 89: 7213-7217.

http://www.pnas.org/content/89/15/7213.full.pdf+h tml

32. Jay, M., 1994. C-Glycosylflavonoids. In: The Flavonoids, Advances in Research Since 1986. Harborne, J.B. (Ed.) Chapman and Hall, London, ISBN: 0-412-48070-0, pp: 57-93.

33. Del Amo, R.S., J.G. Ramírez and O. Espejo, 1986. Variation of some secondary metabolites in juvenile stages of three plant species from tropical rain forest. J. Chem. Ecol., 12: 2021-2028. DOI: 10.1007/BF01041951

34. Hadacek, F., 2002. Secondary metabolites as plant traits: Current assessment and future perpesctives. Critic. Rev. Plant Sci., 21: 273-322. DOI: 10.1080/0735-260291044269

35. Heller, W. and G. Forkmann, 1994. Biosynthesis of Flavonoids. In: The Flavonoids, Advances in Research Since 1986. Harborne, J.B. (Ed.). Chapman and Hall, London, ISBN: 0-412-48070-0, pp: 500-535.

36. Abou-Zaid, M.M. and C. Nozzolillo, 1991. Flavonol glycosides from needles of Pinus banksiana. Biochem. Syst. Ecol., 19: 237-240. DOI: $10.1016 / 0305-1978(91) 90007-M$ 